\title{
Omówienie książki Miry Marcinów „Historia polskiego szaleństwa. Tom I. Słońce wśród czarnego nieba. Studium melancholii"
}

\author{
Fundacja Terytoria Książki, Gdańsk 2017
}

Autorka książki ma wykształcenie filozoficzne i psychologiczne oraz może poszczycić się błyskotliwą karierą naukową. Jej opus magnum, którego studium melancholii jest pierwszym tomem, ma obejmować trzytomową monografię polskiego szaleństwa w XIX wieku. Tom I, zatytułowany „Słońce wśród czarnego nieba. Studium melancholii”, może być jednak rozpatrywany jako niezależna całość i jako taki stanowi niezwykle oryginalną pozycję w polskiej literaturze psychiatrycznej. Poświęcenie pierwszego tomu temu właśnie zagadnieniu wydaje się trafne, jako że melancholia może być uważana za najstarszą psychiatryczną jednostkę chorobową.

„Studium melancholii”" składa się z kilku części. Pierwsza, zatytułowana „Homo psychologicus i polski statek szaleńców", osadza czytelnika w kontekście historycznego spojrzenia na psychiatrię w ogóle i psychiatrię XIX wieku w szczególności. Stosując metodę historiografii idei, autorka stara się m.in. odpowiedzieć na pytanie, czy psychiatria polska miała w tym czasie istotny wkład w rozwój psychiatrii europejskiej czy światowej. Część druga, najważniejsza, zatytułowana „Studium melancholii. Historia dziewiętnastowiecznej zadumy w Polsce", poświęcona jest wnikliwemu omówieniu zagadnienia polskiej melancholii w XIX wieku w kontekście m.in. terminologii i obrazu klinicznego, jak również możliwości terapii. Część trzecia, zwana epilogiem, nosząca tytuł „Źródła do historii dziewiętnastowiecznego szaleństwa w Polsce", stanowi antologię ważnych artykułów naukowych napisanych przez XIX-wiecznych polskich psychiatrów. Ich zbiór jest bogaty i znacznie wykracza poza tematykę melancholii, obejmując m.in. takie problemy, jak psychoterapia, stosowanie placebo czy samobójstwo rozszerzone. W dalszej części książki znajduje się obszerny wybór rycin ilustrujących zagadnienie melancholii i jej pograniczy.

Jeśli chodzi o sam termin „melancholia”, należy wskazać, że w psychiatrii światowej XIX wiek to okres popularyzacji nazwy „depresja”, użytej po raz pierwszy przez lekarza z Edynburga Roberta Whytta (1714-1766), który wprowadził pojęcie „depresji umysłowej” (depression of mind). Na początku XIX wieku próbowano również, bez powodzenia, lansować termin ,lypemania” (pochodzący od greckiego słowa lype - smutek), który zaproponowal francuski psychiatra Jean-Étienne Esquirol (1772-1840), oraz „tristemania” (od łacińskiego słowa tristis - smutny) zasugerowany przez amerykańskiego psychiatrę Beniamina Rusha (1745-1813). Terminu „depresja” użył w końcu XIX wieku lekarz i uczony duński Carl Lange (1834-1900), współtwórca - wraz z Williamem Jamesem - pierwszej neurofizjologicznej teorii emocji (teoria Jamesa-Langego) opisanej w książce „Periodische Depressionzustände und ihre Pathogenesis auf dem Boden der harnsauren Diathese". Oprócz precyzyjnego opisu klinicznego okresowych stanów depresyjnych spełniającego kryteria diagnostyczne XXI wieku Lange przedstawił w niej biochemiczną hipotezę patogenezy depresji jako spowodowanej nadmiarem kwasu moczowego, w efekcie czego rozpoczą podawanie chorym na depresję litu.

Za zwieńczenie osiągnięć XIX-wiecznej psychiatrii uważana jest dychotomiczna koncepcja chorób psychicznych zaproponowana w $1899 \mathrm{r}$. przez Emila Kraepelina. Wyodrębnił on dwie zasadnicze grupy zaburzeń psychicznych na podstawie ich przebiegu i rokowania, nazywając je dementia praecox i manisch-depressives Irresein (obłęd maniakalno-depresyjny). Obłęd maniakalno-depresyjny Kraepelin potraktował szeroko, zaliczając doń zarówno okresowe depresje, jak i chorobę maniakalno-depresyjną. Początkowo termin „melancholia” zachowal tylko dla tzw. melancholii inwolucyjnej, ale rychło włączył go w zakres pojęcia manisch-depressives Irresein. Koncepcja Kraepelina stanowiła podstawę diagnostyki psychiatrycznej XX wieku, a niektóre jej elementy są wciąż aktualne.

Obszar polskich psychiatrycznych dociekań nad melancholią XIX wieku przedstawiony w książce Miry Marcinów rozciąga się między 25. rozdziałem dzieła Ludwika Perzyny „Lekarz dla włościan" opublikowanego w 1793 r. a pracą Mieczysława Nartowskiego pt. „Zaduma (Melancholia)" z 1900 r. Autorce z powodzeniem udało się nakreślić ramy organizacyjne i szpitalne ówczesnej psychiatrii na ziemiach polskich oraz dokonać wyboru najważniejszych artykułów z polskiego piśmiennictwa psychiatrycznego, a następnie na tym tle przedstawić w sposób uporządkowany i odpowiednio zinterpretowany zagadnienia diagnostyczne, kliniczne i terapeu- 
tyczne związane z tematem „Melancholia a sprawa polska w XIX wieku”. Na uwagę zasługuje staranność doboru oraz wnikliwa systematyzacja źródeł. Pod tym względem książka stanowi nieocenioną kopalnię informacji.

Nawiązaniem do światowych rozważań o charakterze semantycznym jest przedstawienie przez autorkę bogactwa polskich określeń melancholii. Oprócz pojęcia „melancholia” w publikacji przywołano bowiem także typowo polskie nazwy, poczynając od terminu „smutnodur” pochodzącego z książki Ludwika Perzyny, a kończąc na nazwie „zaduma” w pracy Mieczysława Nartowskiego. Oprócz tego funkcjonowały takie terminy, jak ponurowatość, posępnica, śledziennictwo, przygnębienie ducha czy wstręt do życia. Nie było natomiast nazwy „depresja”.

Niektóre poruszone w książce zagadnienia, zwłaszcza związane z terapią, znajdują interesujące odniesienia we współczesności - wymienię tylko niektóre z nich. W tym roku obchodzimy 80-lecie wprowadzenia terapii elektrowstrząsowej, niewątpliwie najskuteczniejszej terapeutycznej metody zabiegowej w psychiatrii (m.in. w leczeniu depresji lekoopornej) stosowanej z powodzeniem w XXI wieku. Za datę pierwszego zabiegu uważa się rok 1938 r., kiedy przeprowadzili go włoscy psychiatrzy Ugo Cerletti i Lucio Bini. W książce przytaczane są informacje wskazujące, że prekursorami tej metody leczenia mogli być psychiatrzy polscy. Wśród nich szczególne miejsce zajmuje Klemens Maleszewski (1798-1873) kierujący ośrodkiem psychiatrycznym w Wilnie, który w $1861 \mathrm{r}$ z z powodzeniem zastosował elektroterapię w leczeniu chorego $\mathrm{z}$ katatonią. Tadeusz Nasierowski poświęcił mu artykuł w „Psychiatrii Polskiej” w 2002 r. Dzięki autorce książki dowiadujemy się również, że w latach 70. XIX wieku dwaj inni psychiatrzy, Stanisław Chomętowski i Antoni Munkiewicz, podejmowali próby stosowania elektroterapii w leczeniu melancholii.

$\mathrm{Na}$ s. 159 przytoczona została terapeutyczna koncepcja Józefa Rolle dotycząca konfrontacji melancholijnych poglądów chorego, która może wprost nawiązywać do obecnych zasad terapii behawioralno-poznawczej depresji. Z kolei na s. 160 poruszono wątek pokrewieństwa melancholii i gruźlicy. W tym kontekście należy wspomnieć początek lat 50. ubiegłego wieku, kiedy to zaobserwowano, że izoniazyd i iproniazyd stosowane u chorych na gruźlicę mają działanie przeciwdepresyjne. Dało to początek wprowadzeniu do psychiatrii leków przeciwdepresyjnych z grupy tzw. inhibitorów monoaminooksydazy.

Jako psychiatra specjalizujący się w chorobach afektywnych odczuwam pewien niedosyt w związku z małą liczbą obserwacji dotyczących współwystępowania u pacjentów z melancholią okresowego stanu hipomanii, manii lub tzw. stanu mieszanego. Od czasu Aretajosa z Kapadocji, czyli I wieku naszej ery, wiadomo, że u tej samej osoby mogą występować objawy dwóch biegunów zaburzeń nastroju, czyli depresji (melancholii) i manii. Obecnie wiadomo, że u około połowy pacjentów choroba afektywna dwubiegunowa (maniakalno-depresyjna) rozpoczyna się epizodem depresji. W książce podjęto (s. 195) próbę zasygnalizowania możliwości współwystępowania melancholii i histerii (definiowanej jako skłonność do pobudzenia i nadmiernej ekspresji emocjonalnej) oraz melancholii i osobowości borderline. Z punktu widzenia współczesnej psychiatrii ta ostatnia koincydencja mogłaby mieć pewne znaczenie, jednak w porównaniu z występowaniem stanów depresyjnych i maniakalnych u tej samej osoby stanowi ona bardzo niewielki margines.

Za najważniejsze w tym kontekście uważam przytoczenie przez autorkę na s. 405 tekstu Ludwika Perzyny. W książce „Lekarz dla włościan" Perzyna omawia melancholię, nazywając ją „smutnodurem”, oraz manię, którą określa mianem „szaleństwa”, stwierdzając: „Szaleństwo ze smutnodurem będąc bardzo spokrewnione, trafia się, że pacjenci na przemiany raz od tego, drugi raz od tamtego bywają dręczonymi. Szaleństwo bowiem nie jest niczym innym, jak natężeniem większym smutnoduru". Ludwik Perzyna (1742-1812), którego imię nosi Wojewódzki Szpital Zespolony w Kaliszu, może zatem zostać uznany za polskiego prekursora poglądu dotyczącego występowania manii i melancholii u tej samej osoby, stając się tym samym następcą tak wybitnych lekarzy europejskich, jak Theophile Bonet (1620-1689), Thomas Willis (1621-1675) czy Herman Boerhaave (1668-1738).

Książkę Miry Marcinów oceniam bardzo wysoko. Jej formuła i treść świadczą o wielkiej wiedzy, erudycji i pracowitości autorki. Potencjalny czytelnik na początku może być nawet nieco onieśmielony bogactwem przekazanego materiału, ale ten embarras de richesse można z powodzeniem przezwyciężyć przez wybór najbardziej interesujących pozycji, zwłaszcza z antologii tekstów psychiatrycznych. Zgromadzony i uporządkowany tekst oraz ilustracje stanowią wielce interesującą materię dla psychiatrów, psychologów i wszystkich osób interesujących się zaburzeniami psychicznymi, którym lekturę tej książki gorąco polecam.

Janusz Rybakowski 